\title{
Performance Practice Review
}

Volume 2

Number 1 Spring

Article 8

1989

\section{"Dance Rhythms of the French Baroque: a Handbook for \\ Performance" By Betty Bang Mather, assisted by Dean M. Karns}

Meredith Little

Follow this and additional works at: https://scholarship.claremont.edu/ppr

Part of the Music Practice Commons

\section{Recommended Citation}

Little, Meredith (1989) "'Dance Rhythms of the French Baroque: a Handbook for Performance" By Betty Bang Mather, assisted by Dean M. Karns," Performance Practice Review. Vol. 2: No. 1, Article 8. DOI:

10.5642/perfpr.198902.01.8

Available at: https://scholarship.claremont.edu/ppr/vol2/iss1/8

This Book Review is brought to you for free and open access by the Current Jounrals at Scholarship @ Claremont. It has been accepted for inclusion in Performance Practice Review by an authorized editor of Scholarship @ Claremont. For more information, please contact scholarship@cuc.claremont.edu. 
Betty Bang Mather, assisted by Dean M. Karns: Dance Rhythms of the French Baroque: a Handbook for Performance. Music: Scholarship and Performance. Edited by Thomas Binkley. Bloomington: Indiana University Press, 1987. xiv, 334p.

Betty Bang Mather's book is particularly valuable to performers, who need to realize that dance rhythms underlie much French baroque music, and who also may wish to comprehend these rhythms from the point of view of educated musicians of 17 th-century France. Performance practice scholarship has moved away from its "plug in the correct ornament, or correct tempo" phase and is rightfully searching out the mind-set, attitudes, and understandings of composers and performers of another culture, pursuing the end of recreating these understandings in the modern performer. Mather's text clearly moves in this new direction. The book will benefit not only students but experts with long experience in the field, since it incorporates much recent and even some unpublished research.

Unfortunately, the book's strength - clarity of presentation - is at the same time its weakness. Many of the topics discussed concern areas in which there is profound disagreement among scholars, either because the voluminous source material has not yet been assimilated, or because sources are entirely lacking. Mather often presents her own solution to a complex issue in such a way that the uninitiated reader might accept it without question, thus hiding the anguished debate which rages in the background. For example, in chapter 15 which covers the controversial topic of French agréments, Mather makes a quick case for beginning trills in Lully's dance pieces on the main pitch (p. 177), but cites as authority only Borjon's 1672 musette tutor and two tutors by Jean Rousseau. One need only consult David Fuller's "Ornamentation" in the New Harvard Dictionary of Music (Cambridge and London, 1986) to realize that dozens of contradictory sources cloud this issue. On the same page she states, "Early manuscript and printed copies of Lully's stage works show that no more than an occasional trill or pair of quick notes decorates most of Lully's dance pieces." This is simply not true; many dances do have numerous agréments. The underlying problem, which Mather does not mention, is that none of Lully's music exists in a modern critical 
edition, and no autograph manuscripts exist either. Much of Lully's dance music from the $1650 \mathrm{~s}$ and $1660 \mathrm{~s}$ is presently available only to scholars who have access to manuscript sources scattered throughout European libraries, and scholars are still unsure which of the many prints and manuscripts best represent the composer's intentions. In fact, some manuscripts have more agréments than others, and it is likely that we may never know just how many ornaments Lully preferred for the performance of his dance music. On page 68 another such statement appears: "most Lullian dance lines [are] fitted to two or four musical measures of equal length." Again, this is not true, and the eventual publication of Lully's early ballets will present a much greater variety in phrase length. Furthermore, several of Lully's dance types - the gigue, loure, and courante - have unbalanced phrases as one of their main characteristics.

In the area of belle danse there are further oversimplifications. The most misleading is Mather's constant reliance upon dance information from Thoinot Arbeau's treatise, Orchésography, published in 1589. It is tempting to use Arbeau to explain the grand siecle because his information, like Mather's is clearly presented, and because there is nothing else to rely on (almost no other choreographies are extant in French sources between Arbeau and the year 1700, when the Feuillet collections began publication; Lorin's 1688 manuscripts contain English country dances). But this is not enough reason to quote Arbeau! His style reflects that of the French and Italian dancing of his day, and no connection has yet been established between Arbeau and the distinctive new French style which arose at the court of Louis XIV and was admired and emulated throughout much of Europe during the century that followed.

On page 107 Mather speaks of "the extreme regularity of belle danse choreographies." This is misleading as well as incorrect. The published studies of belle danse all praise the manner in which choreographers avoided regularity (see Anne Witherell's 1982 dissertation "Louis Pécour's 1700 'Recueil de danses,"' UMI Research Press, 1983, and Wendy Hilton's Dance of Court and Theater, Princeton Book Company, 1981, for recent explorations of the dances.) On page 273 Mather discusses the timing of menuet step-units, but without stating that this is an area in which the large variety of source material has led scholars to differing interpretations (for example, see Hilton's above-mentioned book, pages 191-95). Since page numbers are omitted from Mather's references, it is difficult to verify her conclusions. 
Another misleading aspect of the book is the unidentified photograph of two dancers in the frontispiece; some readers may believe that these are seventeenth-century performers, but they are not, and the arms are wrong. In other places there are inaccuracies. For example, on page 264 the brunette is defined as a vocal form popular in the mid-eighteenth century, whereas in fact brunettes were popular from the late seventeenth century on; the dates of publication for the annual collections of notated choreographies for ball dancing (page 94) should be 1702-25, not 1700-22.

Despite these caveats Mather's book elucidates many facets of rhythm which performers of French baroque music often fail to consider: the reason-passion dichotomy in classical rhetoric, Mersenne's application of Greek metrical feet to French dance, the step-units and symmetrical floor patterns of la belle danse, the concept of musical measure and its relation to meter signs, and the rhythmic and rhetorical structure of French poetry set to dances such as the bourrée and menuet. Mather clearly explains and shows how to apply the important recent research of musicologists such as Patricia Ranum (rhetoric and poetry in seventeenth-century French dances, 1981-86); George Houle (meter and music, 1600-1800, 1987); Richard Hudson (origins and early characteristics of the sarabande, passacaglia, chaconne, and folia, 1970-86); Wendy Hilton and Anne Witherell (la belle danse, 1981 and 1982, respectively); Richard Pinnell (baroque guitar strumming and plucking in the work of Francesco Corbetta, 1980); John Hsu (French baroque viol techniques, 1981).

Part I of Mather's book consists of 17 chapters, each a short, carefully thought-out vignette on a subject. Each deepens a performer's understanding of rhythm in French baroque dance music. Particularly interesting is the sixth chapter, which draws on the work of Patricia Ranum to show the correspondence of melodic and poetic rhythms in Lullian dance songs such as the bourree and gavotte. Part II discusses the application of these concepts to 15 French baroque dance types, from allemande to sarabande. An appendix contains six complete dance songs with analysis derived from rhetorical principles; accurate bibliography, endnotes and index complete the book. 